\title{
Izpodbijana junaka - Gavrilo Princip in Rudolf Maister kot subkulturni ikoni
}

Mitja Velikonja

\section{UVOD}

Kdo ali kaj so, razen dejstva, da gre za zgodovinske osebnosti, Lenin, Beethoven, Che Guevara, Franz Ferdinand, Gomulka, Obilić? Znamka vodke, bernardinec iz istoimenske hollywoodske uspešnice, vrsta cigaret, škotski indie-rock band, vzdevek za poljski vlak, beograjski nogometni klub. Michelangelo, Leonardo, Raffaello, Donatello - italijanski mojstri čopiča ali Ninja Turtles? Hemingway - ameriški nobelovec ali veriga barov po vsem svetu? Tito - voditelj socialistične Jugoslavije ali zeliščni liker? Vsi so oboje - in še marsikaj več kot to. Kulturološko so njihove dejanske zgodovinske vloge in usode prav tako pomembne kot njihove današnje kulturne reinterpretacije in prisvojitve. Oba položaja sta legitimni temi preučevanja ter zahtevata ustrezno teoretsko in empirično obravnavo. 
Stoletnice dramatičnih dogodkov in prve svetovne vojne niso obeležili le uradni diskurzi, kot so nacionalno zgodovinopisje, popularna znanost, medijska poročila, množična kultura, sistem spomenikov ipd., ampak tudi tisti robni. Tipična primera sta obravnavi Gavrila Principa (1894-1918), pripadnika Mlade Bosne ${ }^{\mathbf{1}}$ in atentatorja na habsburškega nadvojvodo in prestolonaslednika Franca Ferdinanda, ter generala Rudolfa Maistra Vojanova (1874-1934), poveljnika jugoslovanskih sil na Spodnjem Štajerskem in Koroškem v zapletenih letih 1918 in 1919, poleg tega pa še pesnika. Uradno sta bila avstro-ogrska državljana, a sta se borila proti Avstriji neposredno pred vojno ali takoj po njej. Kot praviloma pri vseh pomembnih osebnostih je njuna zgodovinska vloga kontroverzna in izpodbijana z več strani. Za Slovence je Maister borec za severno mejo, za Avstrijce pa mariborski klavec zaradi njegovih strogih ukrepov zoper nemško govoreče Mariborčane. Principova podoba presega takšen preprost binarizem in je veliko bolj zapletena. Za pokušino uvodoma navajam precej simptomatično primerjavo njegovih opisov $\mathrm{v}$ Wikipedijinih člankih $\mathrm{v}$ šestih različnih jezikih iz leta 2017. V angleškem je »Jugoslovan, ki je umoril nadvojvodo Franca Ferdinanda «; $v$ bosanskem $»$ srbski nacionalist in član organizacije Mlada Bosna «; v hrvaškem » atentator na Franca Ferdinanda in član jugoslovanske organizacije Mlada Bosna «; v srbskem »član tajne skupine znotraj širšega gibanja Mlada Bosna, ki je umoril avstro-ogrskega prestolonaslednika Franca Ferdinanda «; v srbohrvaškem »jugoslovanski nacionalist in revolucionar, ki je umoril avstro-ogrskega prestolonaslednika Franca Ferdinanda « in v nemškem »nacionalistični atentator bosansko-srbskega rodu, ki je izvršil atentat na avstro-ogrskega prestolonaslednika Franca Ferdinanda in njegovo ženo Sofijo v Sarajevu 28. junija 1914«.

Namen pričujoče študije je primerjati in raziskati vizualne reprezentacije Gavrila Principa in Rudolfa Maistra, sodobnikov iz usodnega obdobja tik pred prvo svetovno vojno in tik po njej, ter pomene njunih različnih podob v sodobni urbani krajini. Najbolj me zanima, kako se pojavljata na grafitih in $\mathrm{v}$ street artu $\mathrm{v}$ postjugoslovanski regiji, (ki ima, to je treba izpostaviti že na začetku, bogato tradicijo grafitiranja in street arta). Na kratko: raziskujem njuno ulično uzurpacijo $s$ strani zelo različnih sodobnih subkulturnih in subpolitičnih skupin. Drugače rečeno, raziskujem načine, kako te podobe vizualno strukturirajo sodobne politične razmere. Opazil sem, da sta se število in raznolikost njima posvečenih grafitov in street arta izrazito povečala 
v zadnjih dveh desetletjih, torej dolgo pred obeleževanjem stoletnice prve svetovne vojne.

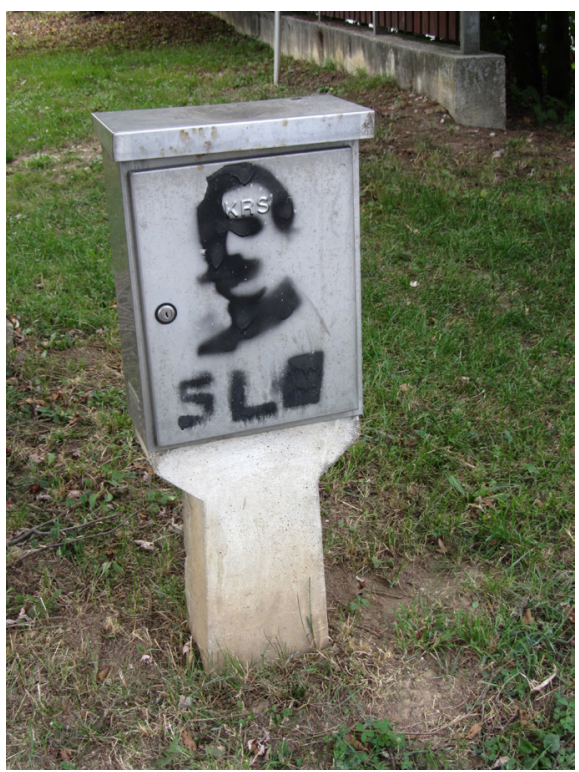

Slika 1: Rudolf Maister, šablona, Ljubljana, 2013 (foto: Mitja Velikonja).

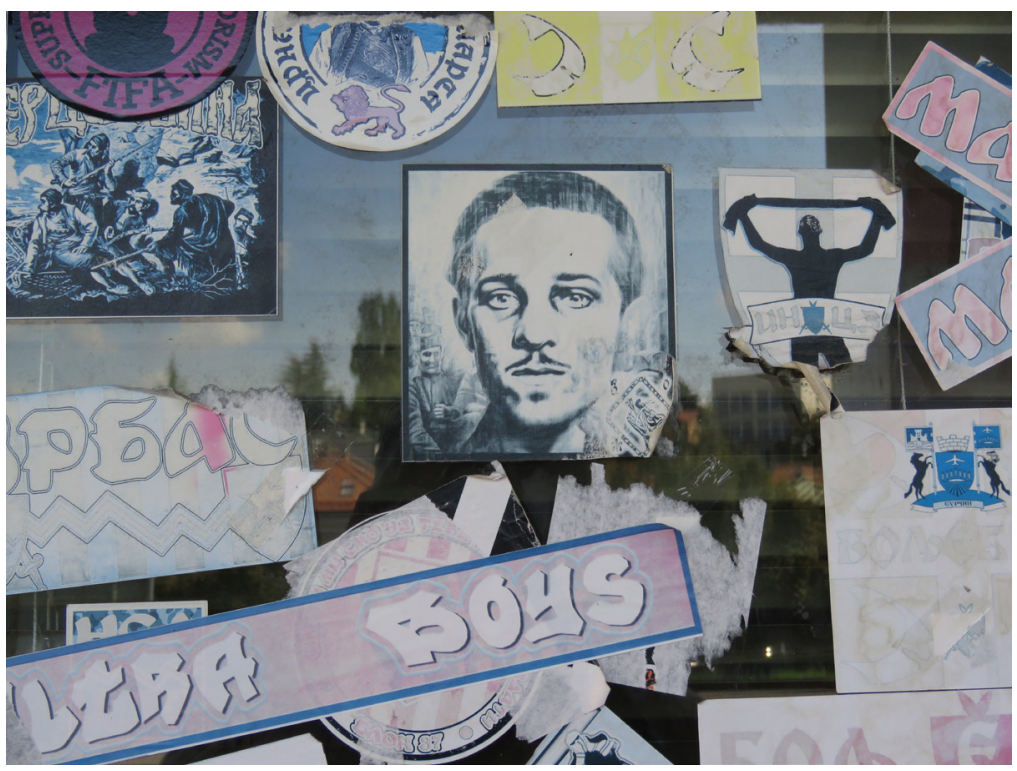

Slika 2: Gavrilo Princip, nalepka, Beograd, 2016 (foto: Mitja Velikonja).

Veliko bolj kot njuna zgodovinska vloga me zanima, kako se pojavljata v javnem prostoru nekdanjih jugoslovanskih republik, torej, 
kako sta videti $z$ daj in ne prej. Njune podobe so - kot vsak drug znak na zemljevidih pomena sodobnih družb - polisemično odprte, na videz nevtralne in kulturno horizontalne, a so vanje še kako močno vpisane različne ideologije, ki ustvarjajo vertikalne pomene ter podpirajo/kritizirajo razmerja moči v družbi. V teoretskem smislu moja raziskava študije grafitov in street arta kombinira s kritično analizo kulta osebnosti sodobnih političnih voditeljev. Po eni strani se naslanjam na navdihujoče študije Craiga Castlemana (1999), Troya Lovate in Elizabeth Olton (2015) ter Lymana G. Chaffeeja (1993). Slednji glavne značilnosti street arta in grafitov kot množičnega medija opredeli takole (1993: 8-9): to je predvsem skupinski medij (ki ga uporabljajo organizirane politične skupine); je pristranski, nenevtralen, politiziran medij (kritizira, komentira, daje različne pobude); ima kompetitivni, nemonopolni, demokratični značaj (promovira marginalne ideje ali skupine); zanj je značilna neposredna ekspresivnost (sporočila so preprosta, jedrnata in kratka); ne nazadnje je to zelo raznolik medij (uporablja različne tehnike in strategije). Grafiti in street art so danes eden izmed najbolj privlačnih, razširjenih in pitoresknih načinov izražanja političnih pogledov. Po drugi strani v teoretskem smislu precej dolgujem konceptom francoskega zgodovinarja Raoula Girardeta (1986) o kultu osebnosti iz obdobja moderne in tistim avstrijskega socialnega psihologa Klausa Ottomeyerja (2000) iz obdobja postmoderne.

Glavna raziskovalna metoda, ki sem jo uporabil, je semiološka, na sledi tiste, ki so jo razvili njeni klasiki Roland Barthes, Umberto Eco in Stuart Hall. Ta razkrinkava ideološka ozadja kulturnih artefaktov, $\mathrm{v}$ tem primeru urbane vizualne kulture. Semiološka metoda omogoča razumevanje ideološke sporočilnosti grafitov in street arta, struktur moči, ki jih predstavljajo, in praktičnih političnih posledic, ki jih povzročajo. Pri tem se zanašam na Barthesov nasvet (1993: 9), da je to »po eni strani ideološka kritika, ki zadeva jezik tako imenovane množične kulture, po drugi strani pa prvi poskus semiološke analize mehanike tega jezika «. Skupaj sem vzel pod lupo triinštirideset primerov grafitov in street arta različnih oblik (šablone, nalepke, murale itn.), posvečenih Principu in Maistru, ki sem jih v veliki večini posnel sam od leta 2008 na različnih mestih v Sloveniji, Srbiji ter v obeh entitetah Bosne in Hercegovine (v Republiki srbski in bošnjaško-hrvaški federaciji). ${ }^{2}$ Primerjal sem jih s podobnim številom drugih njunih vizualizacij v množični in potrošniški kulturi, umetnosti, državnih praksah in na uradnih prireditvah. 
Po hitrem detroniziranju partizanskih in komunističnih junakov po letu 1991 se je general Rudolf Maister povzpel na vrh slovenskega nacionalnega panteona kot nesporni nacionalni junak. Postal je del uradne kulture spominjanja, saj mu je posvečenih enajst spomenikov, kipov in spominskih plošč: v Mariboru, ${ }^{3}$ Kamniku, Kranju, Ljutomeru, Uncu, Polenšaku, Ptuju, Cerkvenjaku, Zavrhu in dva v Ljubljani. Večina jih je bila postavljena nedavno, po letu 1991. Maistrovo ime nosi precej ulic in trgov (Ljubljana, Maribor, Celje, Kranj), ${ }^{4}$ ljutomerski park, dve šoli (Kamnik, Šentilj) in mariborska vojašnica. Domoljubna Zveza društev General Maister s svojimi štiriindvajsetimi članicami od leta 1997 izvaja različne aktivnosti, med drugim izdaja revijo Maistrov glas. Od leta 2005 je 23. november državni praznik, Dan Rudolfa Maistra, ki ga obeležujemo po vsej državi. Maister se pojavlja na spominskih kovancih, znamki (1999) in odlikovanjih Slovenske vojske (zlatih, srebrnih in bronastih). Njemu so posvečeni dokumentarec Podoba vojaka: Rudolf Maister, general in pesnik (2013), Koračnica Rudolfa Maistra, sodobna plesna predstava (2013), niz umetniških delavnic, ki jih od leta 1995 pod njegovim imenom organizira Slovenska vojska, in celo razstava $\mathrm{v}$ prostorih slovenskega ministrstva za obrambo (2010). V potrošniški kulturi njegovo ime uporablja nova pivovarna in znamka piva Maister, ${ }^{\mathbf{5}}$ naprodaj pa so tudi kratke majice z njegovo podobo.

Zato ne preseneča, da njegovo ime najdemo na seznamu najpomembnejših osebnosti slovenske zgodovine: po podatkih raziskave Slovensko javno mnenje je leta 2003 zasedal peto mesto (Toš idr. 2004: 468-69), ${ }^{6}$ leta 2012 pa šesto (Toš idr. 2016: 239). ${ }^{7}$

Toda Maistrova podoba se je najbolj zakoreninila na drugem robu sodobne slovenske družbe: $\mathrm{v}$ naredi-si-sam kulturi nogometnih navijačev in $\mathrm{v}$ skrajno desničarskih političnih skupinah. Prvič: postal je ena najprepoznavnejših ikon $V i o l$, navijačev v zadnjih letih z naskokom najmočnejšega nogometnega kluba Maribor, ki so ga popolnoma monopolizirale. Največji vojaški uspeh generala Maistra je bil prevzem borci za severno mejo, ki ga je ustvaril Drago Tršar.

44 Stanovalci Maistrove ulice v Mariboru organizirajo celo vsakoletni kulturni dogodek $\mathrm{z}$ naslovom Maistrovanje.

5 Ta ponosno naznanja, da se po skoraj sto letih General Maister vrača v Maribor. http://pivopis. si/dogodek/predstavitev-pivovarne-maister/, dostop 23. september 2016.

6 Takoj za literatoma Francetom Prešernom in Primožem Trubarjem ter politikoma Milanom Kučanom in Josipom Brozom Titom. 


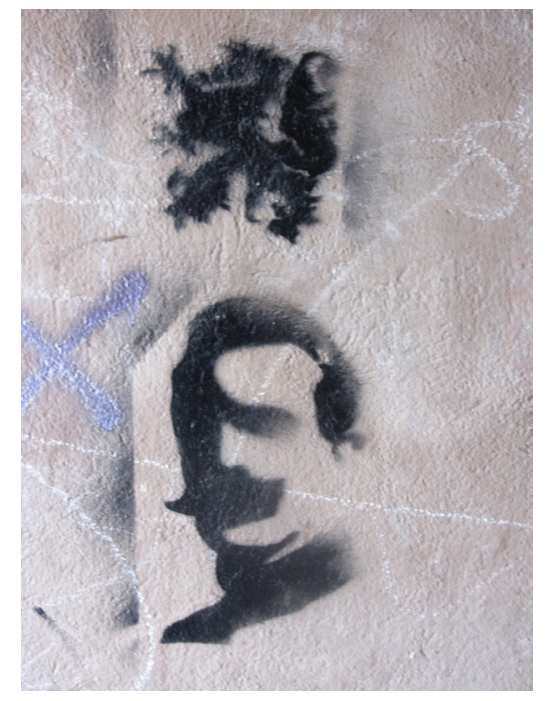

Slika 3: Rudolf Maister, šablona, Celje, 2011 (foto: Mitja Velikonja).

oblasti v Mariboru novembra 1918 in osvoboditev Spodnje Štajerske v naslednjih nekaj mesecih: zato je razumljivo, da je bolj popularen v severovzhodni Sloveniji kot drugje. Njegov portret se pojavlja na navijaških nalepkah, panojih, našitkih, kratkih majicah, podlagah za miške ipd.; navijači glasno proslavljajo njegov praznik (23. november), njegovo podobo najdemo na njihovi spletni strani ${ }^{8}$ in v njihovih pesmih. ${ }^{9}$ Eden izmed pozivov je Vsi na Maistra!, kar pomeni Dobimo se pri Maistrovem spomeniku! in se skupaj odpravimo na tekmo.

In drugič: Maister se v obliki računalniških ozadij ali panojev pojavlja v vizualnem imaginariju treh slovenskih radikalno desničarskih skupin: Tukaj je Slovenija!, Hervardi ter Avtonomni nacionalisti Slovenije. Novi Maistrov spomenik pred ljubljansko avtobusno in železniško postajo je njihova zbirna točka pred odhodom na različne proteste. Poleg Hervardov so se med mariborskimi vstajami v zadnjih

8 http://www.violemaribor.com/viole/512-rn23november.html, dostop 22. september 2016.

9 Štajerska je naša

ljubimo jo mi!

kdor ne ljubi Štajerske

koljemo ga mi.

Prišo bo prišo

drugi Rudolf Maister

Štajerska do Tokia

samostojna država!

http://www.violemaribor.com/viole/multimedia/62-pesmi/244-rudolf-maister.html, dostop 22. septembra 2016. 
mesecih leta 2012 in zgodnjih 2013 nanj sklicevali tudi v nota bene, Maistrovi armadi. ${ }^{\mathbf{1 0}}$ Raziskovalka subpolitičnih skupin Monika Kropej (2016) je identificirala štiri glavne značilnosti njegove podobe med nogometnimi navijači in mladimi desničarji: njegov patriotizem, junaštvo, osvoboditev Spodnje Štajerske, a tudi njegovo pesniško plat.

Maistrovo podobo sem našel tudi na njihovih šablonah in nalepkah (ne pa na grafitih, muralih ali plakatih). ${ }^{\mathbf{1 1}} \mathrm{Na}$ večini je predstavljen dokaj »nevtralno «, torej zgolj portret v vojaški opravi (včasih je dodan še njegov podpis), medtem ko so mu na nekaterih dodani desničarski simboli in gesla (podobe karantanskega panterja ali domobranskega orla, pa tudi ksenofobna sporočila tipa Čefurji Raus ali žalostna klasika Slovenija Slovencem).

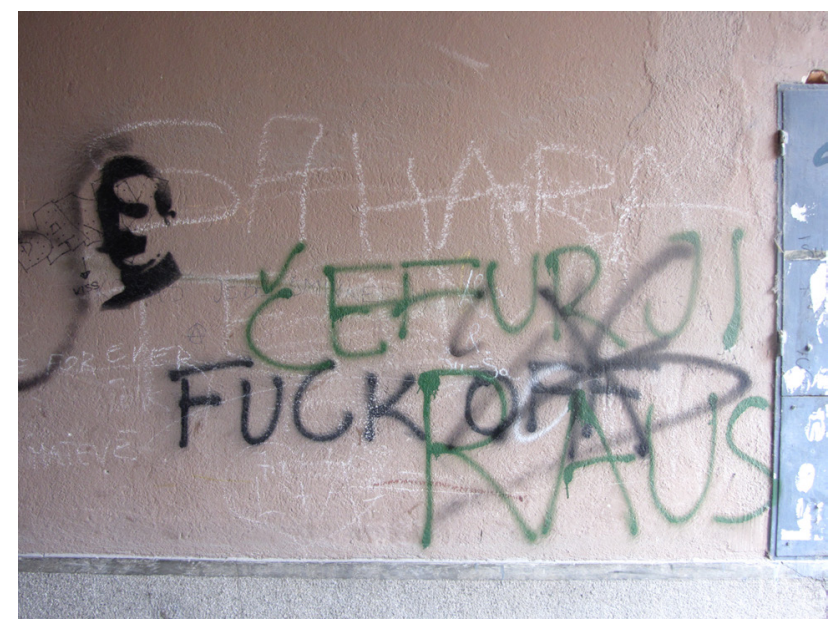

Slika 4: Rudolf Maister, šablona, Celje, 2014 (foto: Mitja Velikonja).

\section{PODOBA GAVRILA PRINCIPA V (NE)URADNIH VIZUALNIH}

\section{DISKURZIH}

Vizualna apropriacija Gavrila Principa je zelo podobna: med vojnama in tudi sedaj, po razpadu Jugoslavije, so ga skorajda, vendar ne popolnoma, monopolizirale srbska nacionalna ideologija in uradne ustanove. V sodobnih srbskih zgodovinskih učbenikih je opisan kot pravi srbski junak (Stojanović 2010: 114, 150). Njegova podoba se pojavi

10 Pričevanje mariborskega aktivista Gregorja Stamejčiča 24. septembra 2016.

11 Večino sem našel v Ljubljani, Mariboru, Celju in Novi Gorici. 
na naslovnici zelo problematične knjige Istorija Republike Srpske, ki poveličuje srbsko entiteto v Bosni in Hercegovini. ${ }^{12}$ Čeprav se je sam imel za jugoslovanskega nacionalista, lahko skoraj vse njegove vizualne upodobitve najdemo le v Srbiji in Republiki srbski.

Znova začenjam na ravni uradne kulture spominjanja. Nova spomenika so mu postavili junija 2014 v Istočnem Novem Sarajevu v Republiki srbski in junija 2015 v Beogradu. Še pred njima, aprila 2014, so njegov kip postavili v Tovariševem v Vojvodini, svečano sta ga odkrila zagrizena srbska nacionalista Emir/Nemanja Kusturica in Matija Bečković. Princip se, skupaj z drugimi protagonisti Mlade Bosne, pojavlja na velikem javnem mozaiku grotesknega Kusturićinega projekta Andrićgrad v Višegradu, Republika srbska. ${ }^{13}$ Principovi posmrtni ostanki so bili končno preneseni v skupno grobnico z drugimi - kot pravi napis - vidovdanskimi junaki iz Mlade Bosne na staro srbsko pravoslavno pokopališče svetega nadangela Mihaela v sarajevski četrti Koševo. ${ }^{14}$ Eno izmed vojaških odlikovanj Miloševićeve Zvezne republike Jugoslavije je bila Zlata medalja Gavrila Principa za pogum. Po njem je poimenovana tudi osnovna šola v Zemunu.

Po mojih podatkih je v Srbiji petnajst ulic z njegovim imenom (Beograd, Kragujevac, Novi Sad, Čačak, Niš, Šabac, Kruševac, Kraljevo, Loznica, Novi Pazar, Sremska Kamenica, Subotica, Vršac, Bačka Palanka in Leskovac), v Republiki srbski pa pet (Banja Luka, Pale, Šipovo, Bijeljina in Vlasenica). Posvečeni so mu tudi park (Istočno Novo Sarajevo), ena ulica v Podgorici in ena v Sarajevu. Originalna plošča s Principovimi odtisi stopal je bila dvakrat namerno odstranjena: prvič po okupaciji aprila 1941 (ko so jo nove oblasti takoj poslale Hitlerju kot bizarno rojstnodnevno darilo) in drugič med zadnjim obleganjem mesta. Nova na zelo suhoparen način in dvojezično, v bosanščini in angleščini, pojasnjuje: »Na tem mestu je 28. junija 1914 Gavrilo Princip izvršil atentat na avstro-ogrskega prestolonaslednika Franca Ferdinanda in njegovo ženo Sofijo.« Bližnji most čez reko Miljacko so leta 1992 iz Principovega preimenovali v Latinski most.

Principova podoba je veliko bolj kot Maistrova prisotna v potrošniški kulturi: na kratkih majicah ${ }^{\mathbf{1 5}}$ pri uličnih prodajalcih v Beogradu, http://www.marks21.info/analiza-redakcije/izmisljena-istorija nepostojece-drzave, dostop 23. januarja 2017.

14 V času obleganja Sarajeva na to grobnico presenetljivo ni padel niti en sam izstrelek,

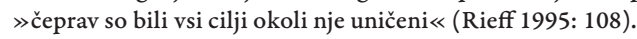


$\mathrm{v}$ trgovinah (predvsem knjigarnah) in $\mathrm{v}$ spletni prodaji. Pojavlja se na različnih parafernalijah: na magnetih, perilu ipd. (glej primere v Novaković, Peters, 2015). Na spletu je mogoče najti z njim povezane bolj ali manj posrečene meme. ${ }^{\mathbf{1 6}}$ Navdihnil je številne umetnike: bosanskega ilustratorja Berina Tuzlića, ${ }^{17}$ srbskega digitalnega grafičnega umetnika in pisca Zorana Spasojevića, ${ }^{\mathbf{1 8}}$ danskega ilustratorja Henrika Rehra, ${ }^{\mathbf{1 9}}$ srbski pisateljici Biljano Srbljanović ${ }^{\mathbf{2 0}}$ in Mileno Marković21 ter srbsko-ameriškega skladatelja Milosa Raickovicha. ${ }^{22} \mathrm{O}$ njem so posneti naslednji filmi: jugoslovanski Sarajevski atentat (1968, režija Fadil Hadžić), kratki angleški The Last Words of Gavrilo Princip (2014, režija Jacqueline Pepall), srbski Branil sem Mlado Bosno (2014, režija Srdjan Koljević), avstrijski Sarajevo (2014, režija Andreas Prochaska) in najbolj znan, češkoslovaško-jugoslovansko-nemška koprodukcija $\mathrm{Sa}$ rajevski atentat (angleško The Day That Shook the World, 1975, režija Veljko Bulajić). Princip je našel svoje mesto tudi v popularni glasbi: srbski nacionalistični turbofolk pevec Baja Mali Knindža ga omenja v pesmi Vratice se delija. ${ }^{\mathbf{2 3}}$

Podobo mladega sarajevskega atentatorja je mogoče najti tudi v neuradnih desničarskih in levičarskih diskurzih ter skupinah. Prvič, je ena izmed redkih skupnih ikon dveh rivalskih beograjskih navijaških skupin, Delij nogometnega kluba Crvena zvezda in Grobarjev nogometnega kluba Partizan, ki se sicer obe močno nagibata na politično desno. ${ }^{24} \mathrm{Na}$ zastavah Delij se pojavlja v družbi drugih srbskih junakov z začetka dvajsetega stoletja, kot sta vojvodi Živojin Mišić in Radomir Putnik. Njegova podoba je tudi zraven tiste Dimitrija Popovića (mladega Srba, ki so ga leta 2004 ustrelili kosovski

Ob you started a shitstorm? - That's cute ali Gavrilo Princip doesn't always start wars But when he does, he starts World Wars ali Assassinate a foreign official, they said - It'll be fun, they said.

17 Znanstvenofantastični grafični roman Sarajevski atentat 2914 (Sarajevo: Pixel, 2014).

18 Glej primere njegovega e-mail arta na http://zoran-spasojevic-portreti.blogspot.ba/2011/05/ gavrilo-princip.html, dostop 5. februarja 2017.

19 Grafični roman Terrorist: Gavrilo Princip, the Assassin Who Ignited World War I (New York: Graphic Universe, 2015).

20 Mali mi je ovaj grob (Beograd: Samizdat, 2013).

21 Zmajeubice -Junački kabare (Beograd: Lom, 2014).

22 The Song of Gavrilo Princip (for tenor and piano), 2014, http://library.newmusicusa.org/ library/composition.aspx ?CompositionID=350486, dostop 23. januarja 2017.

23 Vratiću se ponovo

u Bosansko Grahovo

tamo gde je Gradina

gdje je Princip Gavrilo ...

24 O povezavi med tema navijaškima skupinama in srbsko nacionalistično politiko glej Čolović 2011: 109-33. Kakor koli, Principa kot vsesrbskega junaka častijo tudi navijači nogometnega kluba Radnički iz Kragujevca; takole so posneli ustvarjanje grafita njemu v čast: https://www.youtube.com/watch?v=g1KKFQ40HpA, dostop 22. januarja 2017. 
Albanci), Karađorđa in zemljevida Kosova. ${ }^{25}$ Srečamo ga tudi v vizualni ikonografiji srbskih nacionalistov: samega, v družbi srbskih poveljnikov iz prve svetovne vojne ali četniškega voditelja Draže Mihajlovića (recimo v tatujih).

A za svojega so ga vzeli tudi srbski levičarji: postal je referenca za tamkajšnje anarhosindikaliste, ${ }^{\mathbf{2 6}}$ njegovo ime nosi tudi street-punk bend iz Smedereva. ${ }^{27} \mathrm{~V}$ Bosni in Hercegovini je postal sinonim za odpor: skupina levičarskih aktivistov je 28. junija 2014 na protestih pred sarajevsko mestno hišo nosila maske z njegovim obrazom. Na svojih panojih je trdila, da je Bosna spet okupirana, tokrat s strani Evropske unije, mednarodne skupnosti, fašistov, Mednarodnega denarnega sklada, kapitalizma in nacionalizma, ter se predstavljala kot Gavrilo Princip (Ja sam Gavrilo Princip, ne barći u BiH - Jaz sem Gavrilo Princip, rokeproč od Bosne in Hercegovine). ${ }^{\mathbf{2 8}}$ Istega leta so v $\mathrm{BiH}$ o njem posneli dve pesmi. Hercegovski alter-pop in reggae bend Zoster mu je posvetil pesem Gavrilo, ki lepo ujame njegov mladostniški pogum in ranljivost, pa tudi njegovo današnjo ideološko ambivalentnost; ${ }^{29}$ eksperimentalni pevec Dječak iz Vode $(\mathrm{DiV})^{\mathbf{3 0}}$ iz Brčkega pa je o njem objavil parodijo Sasvim neobični slučajevi (Lukec 2016).

Za razliko od Maistrove se Principova podoba na ulicah pojavlja $\mathrm{v}$ različnih tehnikah (grafiti, murali, nalepke in šablone) ter skoraj vedno kombinira sliko (njegov portret) in besedilo (povečini v cirilici). ${ }^{\mathbf{3 1}}$ Nekaj

https://footballpink.net/2015/07/21/red-star-and-the-land-of-great-knights/, dostop 2. oktobra 2016.

https://www.facebook.com/borbenisindikat/posts/223022167820345, dostop 22 . septembra 2016.

Glejnjihovafacebook profilahttps://www.facebook.com/Gavrilo-Princip-313844262159605/ in https://www.facebook.com/gavriloprincip82. Gavrilo Princip je, zanimivo, ime tudi nekega italijanskega indie-rock benda. Drugi protagonist atentata ima prav tako »svoj bend «: gre za škotsko indie-rock zasedbo Franz Ferdinand. Njena pesem All For You Sophia (2004) vključuje naslednje verze:

\section{Bang, bang, Gavrilo Princip \\ Bang, bang, shoot me, Gavrilo \\ Bang, bang, the first six are for you \\ Bang, bang, the seventh is for me \\ Bang, bang, Gavrilo Princip \\ Bang, bang, Europe's going to weep ...}

$\mathrm{Na}$ koncertih včasih nastopa pred ogromnim platnom $s$ Principovo podobo ...

$\mathrm{V}$ isti mestni hiši so stoletnico atentata istočasno obeležili s koncertom dunajskih filharmonikov.

Ta vključuje te pomenljive verze:

Za jedne on je heroj, a drugima je zločinac

a možda negdje na pola puta njegova duša luta ...

Ime je besedna igra: kratico $D i V$ lahko razumemo tudi kot div, kar v bosanščini/ hrvaščini/srbščini pomeni velikan.

31 Najti jih je mogoče v Beogradu, Novem Sadu, Užicu, Pančevu, precej v Banja Luki, Bosanskem Grahovu itn. 


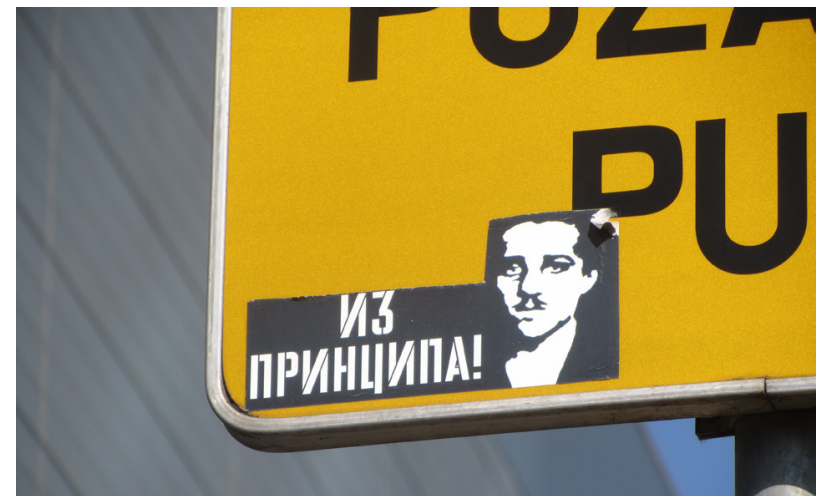

Slika 5: Gavrilo Princip, nalepka, Beograd, 2014 (foto: Mitja Velikonja).

je povsem nacionalističnih (mural Principa skupaj z Mihajlovićem s pripisom $V$ čast našim dedom!, drugi s srbsko zastavo v ozadju; Principova nalepka s srbskim vojakom v ozadju), medtem ko je velika večina napisov ob njegovem portretu bolj abstraktna (recimo Iz principa, Nesmrtni princip ali samo njegovo ime/obraz) ali nedoločno uporniška (z njegovimi citati: Naše sence bodo hodile po Dunaju, blodile po dvoru, strašile gospodo, ali Upor, ali Vsako noč sem sanjal, da sem anarhist, da se ruvams policaji, ali Nisem želel postati junak, želel sem samo umreti za mojo idejo ali pa dramatična slika atentata na Franca Ferdinanda). ${ }^{\mathbf{3 2}}$

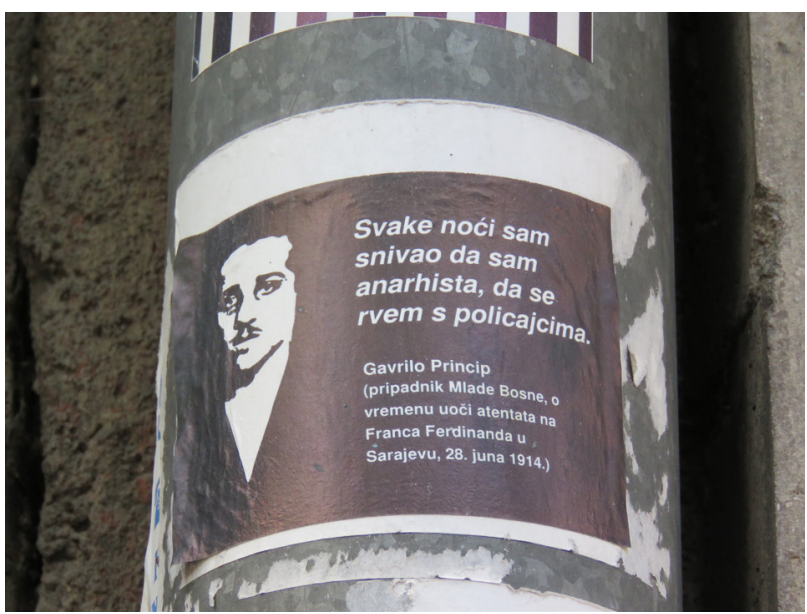

Slika 6: Gavrilo Princip, nalepka, Beograd, 2017 (foto: Mitja Velikonja).

32 Nekatere od njih je mogoče najti v seriji nalepk s silhueto in navedki njegovega soborca iz Mlade Bosne Nedeljka Čabrinovića. 
Po besedah francoskega situacionista Guya Deborda je naloga spektakla »zakopati zgodovino v kulturo « (1994: 57). Raziskovalec ameriške množične kulture George Lipsitz na podoben način govori o »transformaciji resničnih zgodovinskih tradicij in kultur v površne ikone in slike «; po njegovem stare oblike »izgubijo sposobnost narekovati in interpretirati izkušnjo, a kljub temu vztrajajo kot pomembne ikone odtujene identitete « (1997: 134). Imamo torej tudi v tem primeru opravka z nebolečo degradacijo pomembnih zgodovinskih osebnosti v površne ulične in plitke popkulturne ikone? Menim, da ravno nasprotno: omenjeni primeri kažejo na njihovo reinvencijo, na ponovno rojstvo $\mathrm{v}$ popolnoma novih političnih razmerah in ideološki konstelaciji. Maister in Princip sta danes prav tako pomembna, kot sta bila celo prejšnje stoletje, a na drugačen način, saj različne skupine vanju investirajo različne politične agende.

Najprej bi rad izpostavil nekaj simptomatičnih podobnosti uličnih podob obeh osebnosti, da bi lahko potem poudaril še pomembne razlike med njimi. A še pred analizo bi rad spomnil na pomenljivo dejstvo: čeprav ima (post)jugoslovanska regija razmeroma dobro razvito grafitarsko kulturo, sta se podobi Maistra in Principa pojavili šele nedavno, v zadnjih petnajstih letih. To priča o tem, da ju imajo za svoja vse bolj različne (sub)politične in subkulturne skupine, ter o veliko širšem procesu selitev političnih konfrontacij v različne tipe uličnih kultur, $s$ tem pa tudi na zidove.

Principu in Maistru je skupno, da sta postala del uradnega, kanoniziranega spominjanja obeh narodov, njunih nacionalnih ideologij in s tem sodobnih političnih bojev. Podoba Rudolfa Maistra je trdno usidrana $\mathrm{v}$ uradni slovenski nacionalizem (na ravni vladajočih institucij in hegemonskih diskurzov), pa tudi v $\gg$ ulični « nacionalizem desničarskih subpolitičnih in navijaških skupin. Njegovo podobo borca proti lokalnim nemško govorečim Avstrijcem neposredno po prvi svetovni vojni danes prevzemajo nacionalisti v odporu proti novim tujcem, ${ }^{33}$ Viole pa tudi v konfrontacijah z drugimi slovenskimi navijaškimi skupinami. Podobo Gavrila Principa danes izkoriščajo predvsem različne srbske nacionalistične institucije ter subpolitične in subkulturne skupine. Kljub temu, da sta bila oba 
projugoslovansko usmerjena, ${ }^{\mathbf{3 4}}$ sta danes predvsem nacionalistični ikoni: na političnih grafitih in $\mathrm{v}$ street artu celo še bolj kot $\mathrm{v}$ drugih urbanih vizualijah. Nacionalistična ideologija zase vedno trdi, da ni nacionalistična (sebe definira onstran politične levice ali desnice) ter se pozicionira »nepolitično « oziroma »neideološko«. Odveč je pripomniti, da je prav to najbolj ideološka pozicija od vseh, saj svojo partikularnost skriva za tančico »skupnega dobrega «. Zato se portreti Maistra in Principa (in včasih njuni citati) pogosto pojavljajo na grafitih, muralih, šablonah in nalepkah brez izrecnih nacionalističnih dodatkov: njuna »nevtralnost « implicira, da je popolnoma jasno, da sta se borila za našo, slovensko oziroma srbsko, stvar, »brez ideološkega predznaka «.

Obstaja pa tudi niz pomembnih razlik med sodobnimi urbanimi reprezentacijami Maistra in Principa. Principovih je veliko več. Maister je $\mathrm{v}$ slovenski nacionalistični diskurz močno zasidran kot pomemben slovenski junak: a ostaja na tej lokalni ravni, malokdo izven Slovenije je sploh slišal zanj. Za razliko od Maistrovega ekskluzivizma je Principova podoba precej bolj inkluzivna, bolj odprta za interpretacije: njegovi streli »so se slišali daleč po vsem svetu « (Mojzes 1994: 32) in njegovo dejanje je fasciniralo mnogo širši krog ljudi. ${ }^{35}$ Njegovo morilsko dejanje je postalo globalni sinonim za umor pomembne politične osebnosti, ki ima velike posledice. ${ }^{36}$

34 Maister je uradno poveljeval jugoslovanskim in ne slovenskim vojaškim silam, (čeprav so večino moštva sestavljali etnični Slovenci): najprej kratkotrajne in mednarodno nepriznane Države Slovencev, Hrvatov in Srbov, od 1. decembra 1918 pa Kraljestva Srbov, Hrvatov in Slovencev. Znameniti razglas 9. novembra 1918 začenja z Državljani, Jugoslovani! Resni zgodovinarji prav tako ugotavljajo, da so bili Princip in drugi pripadniki Mlade Bosne nedvomno jugoslovanski revolucionarji: »skupen jim je bil ohlapen koncept republikanske, enakopravne jugoslovanske federacije « (MacKenzie 1989: 137); »povečini so bili revni bosanski študentje, prežeti z anarhističnimi in domoljubnimi ideali« (Deák 1990: 75); njihov cilj je bila »ustanovitev napredne, anarhosocialistične jugoslovanske države in posledično takšnega sveta (Deák 1996: 13); »borili so se za neodvisno federativno državo jugoslovanskih ljudstev« (Galántai 1989: 25). Po besedah zgodovinarja Vladimirja Dedijerja je bila Mlada Bosna heterogena, politično napredna tajna skupina »z enim skupnim ciljem: revolucionarno uničenje habsburške monarhije « (1978/I: 223) in »osvoboditev južnih Slovanov« (1978/II: 23, glej tudi 237): eksplicitno so se prepoznavali, vključno z Gavrilom Principom, kot $\gg$ Jugoslovani« (Dedijer 1978/II: 22).

35 Velja samo pogledati, kolikokrat je omenjen v potopisni knjigi Rebecce West (1943).

36 Novinarji so atentat na ruskega ambasadorja v Turčiji Andreja Karlova decembra 2016 večkrat primerjali s tistim na Franca Ferdinanda junija 1914. Glej recimo http://www.express.co.uk/ news/world/745301/World-War-1-Russian-ambassador-murder-Turkey-Franz-Ferdinand, dostop 31. januarja 2017. 




Slika 7: Rudolf Maister, šablona, Nova Gorica, 2010 (foto: Mitja Velikonja).

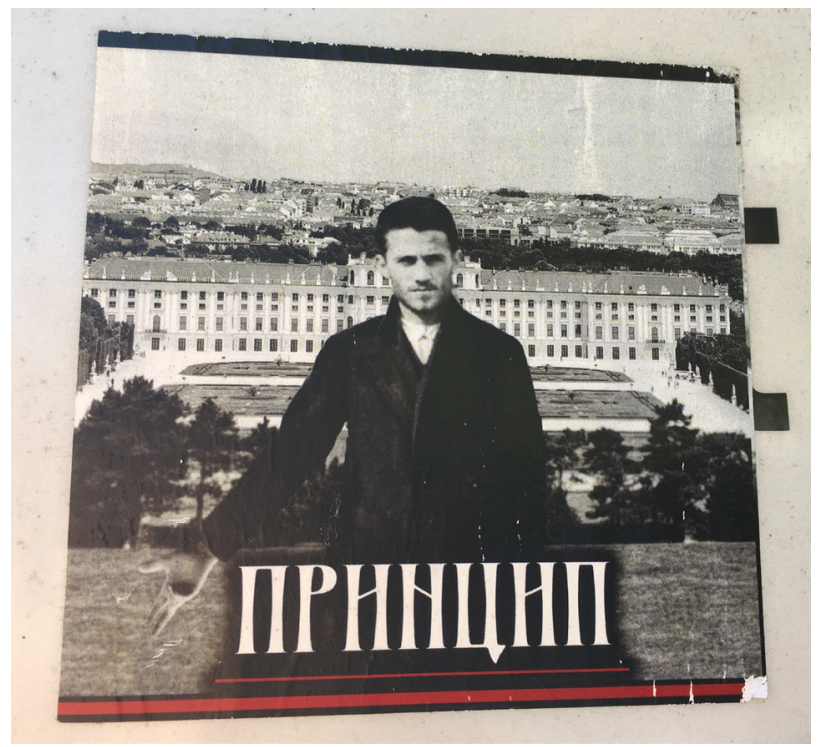

Slika 8: Gavrilo Princip, nalepka, Vranje, 2015 (foto: Mitja Velikonja).

Princip je bil (in je še) integriran v tri vzporedne in medsebojno antagonistične ideološke paradigme in politične prakse. Prvič in predvsem so ga temeljito »posrbili«, in to kljub dejstvu, da v tistem času ni predstavljal uradne srbske politike. ${ }^{37}$ Kljub temu so ga vključili v dolgo vrsto pomembnih Srbov, ki se vleče od kosovske bitke, kot enega izmed vidovdanskih junakov (Jezernik 2013: 32; glej tudi Mønnesland 2013: 42-3); čeprav ne kot najpomembnejšega, temveč enega od mnogih. Ta na svojo roko ali sta preprosto izvrševala ukaze tajne vojaške organizacije Črna roka polkovnika Dragutina Dimitrijevića-Apisa, glej MacKenzie 1989: 123-37. 
uzurpacija se je ohranila do danes tako $\mathrm{v}$ vladajočih ustanovah in diskurzih $^{\mathbf{3 8}}$ kot tudi v subpolitičnih in subkulturnih skupinah. Drugič, v jugoslovanskih časih » so slavili Gavrila Principa kot junaka, kot nosilca ideje o svobodi in jugoslovanstvu « (Dragićević Šešić 2014: 74). Dedijer je njegov atentat na Franca Ferdinanda navezal na domnevno $\gg$ staro srbsko-hrvaško folklorno teorijo o uboju tirana « (Čolović 2016: 351-56). Toda zagovorniki jugoslovanske ideje in Jugoslavije so ideološki boj za nasledstvo Principa (in Mlade Bosne) izgubili s srbskimi nacionalističnimi revizionisti, čeprav je bil Princip deklariran ateist in republikanec, ki se je zavzemal za ustanovitev države Jugoslovanov. Bil je torej projugoslovansko, ne pa prosrbsko usmerjen (glej Lampe 1996: 89, 98 in Popović 2016). Delni razlog za marginalizacijo njegove jugoslovanske usmeritve je v tem, da je prva Jugoslavija vse zasluge za zedinitev pripisala dinastiji Karađorđević, druga pa Titu in narodnoosvobodilnemu boju. Tretja ideološka paradigma je veliko manj razširjena: Princip je zaradi svojih jasno izraženih anarhističnih prepričanj ohranil avtentično uporniško, protisistemsko in protiimperialistično identiteto ter simbolizira nedefinirano, a pogumno kljubovanje kakršni koli okupaciji in oblasti nasploh (avstro-ogrski pa še posebej). Zato ga slavijo tudi na politični levici in je postal širši simbol upora zoper oblast.



Slika 9: Rudolf Maister, nalepka, Maribor, 2014 (foto: Mitja Velikonja). zgodovinarja Radoša Ljušića (Čolović 2016: 395, 440). Slednji Principa neposredno imenuje nacionalni junak. Miloš Crnjanski ga v pesmi Spomen Principu prav tako povezuje s srbsko srednjeveško in vidovdansko tradicijo. A po drugi strani Principa, presenetljivo, ni mogoče najti na seznamu sto najpomembnejših Srbov v zgodovini v istoimenski knjigi (Beograd: Principi; Novi Sad: Š-Jupublik, 1993). 


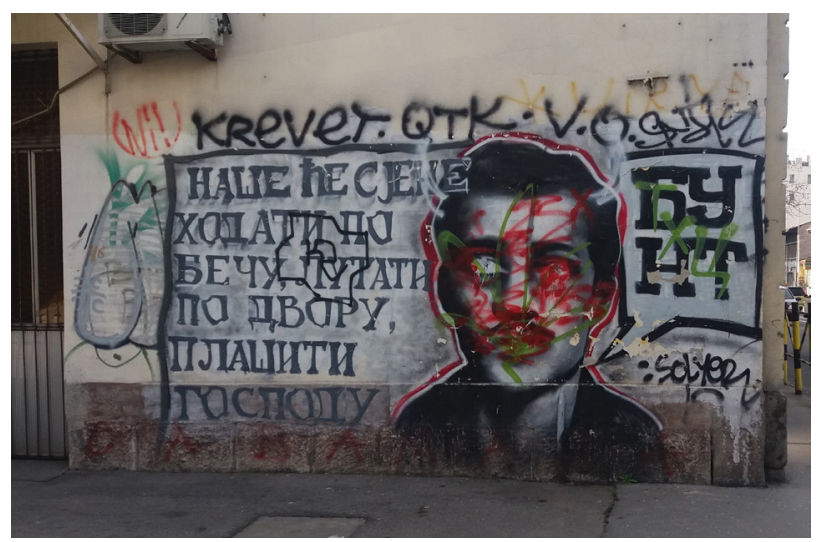

Slika 10: Gavrilo Princip, mural, Beograd, 2017 (foto: Mitja Velikonja).

Dalje: Maistrove podobe skoraj ni mogoče najti izven politike in subkulture nogometnih navijačev, medtem ko je Principova razširjena tudi v množični kulturi, umetnosti, dizajnu in potrošništvu. In zadnji pomembni razliki med njunima vizualnima reprezentacijama: Maister se ne sooča z nikakršno simbolno opozicijo iz tistih časov nihče dejansko zares ne slavi njegovih nasprotnikov iz let 1918 in 1919. V Principovem primeru pa Franz Ferdinand (in njegova žena Žofie Chotková) nastopata kot njegovi nasprotji, (povečini) v potrošniški kulturi v današnjem Sarajevu: tam so odprli Hostel Franz Ferdinand, Franz Ferdinand Apartments in čajnico Franz \& Sophie, turistom pa je namenjena tudi Sarajevo: 1914 Archduke Assassination Tour, ${ }^{39}$ mogoče pa je tudi kupiti razne spominke s prestolonaslednikovo podobo. ${ }^{\mathbf{4 0}}$

Maistra lahko v Girardetovi tipologiji junakov prepoznamo kot lokalno inkarnacijo mita o Mojzesu (1986: 78-80), torej kot izkušenega in daljnovidnega voditelja, osvoboditelja in zaščitnika, ki svoje ljudstvo vodi v prihodnost in uteleša voljo po svobodi, (ki je bila takrat povezana $\mathrm{z}$ združitvijo z drugimi Jugoslovani, danes pa s samostojnostjo Slovenije). Principova podoba je mnogo bolj ambivalentna kot Maistrova in se v Girardetovi tipologiji uvršča v Aleksandrov mit (1986: 74-7). Predstavljen je kot mlad, neustrašen bojevnik, kot navdahnjen pustolovec, ki se bori za velik cilj, a zgodaj umre: torej kot junak nacionalističnega projekta (srbskega ali jugoslovanskega) ali kot junak globalnega odpora kakršni koli oblasti. Njuni sodobni podobi imata veliko več skupnega s klasičnimi značilnostmi »junakov starega kova «, torej takih, ki so nad ali pred 
ostalimi ljudmi, ki jim brezpogojno sledijo, kot s sodobnimi junaki, kot jih razlaga Ottomeyer (2000). ${ }^{\mathbf{4 1}}$

Vizualne - in v zadnjem času tudi ulične - reprezentacije Rudolfa Maistra in Gavrila Principa potujejo skozi čas, njihovi pomeni pa niso trdni, ampak nenehno na novo izumljeni in izpodbijani, odvisni od hegemonskih/protihegemonskih (torej vladajočih/opozicijskih) političnih diskurzov $\mathrm{v}$ okoljih, $\mathrm{v}$ katerih sta pomembna. $\mathrm{Z}$ Barthesovimi besedami (1993: 144): »Odnos ljudi do mita ne temelji na resnici, ampak na uporabi: ljudje depolitizirajo glede na svoje potrebe. « Tako Maister kot Princip lahko zlahka postaneta del ideoloških kompozicij vedno novih nacionalizmov, slednji pa tudi nove levice. Kakršna koli predvidevanja o njunih bodočih transformacijah - razen da se bosta čedalje pogosteje pojavljala tudi v novih medijih - so negotova. Toda glede na radikalizacijo ideoloških diskurzov in političnih praks $\mathrm{v}$ zadnjih letih lahko sklenem, da bo trend njunih vizualnih predstavitev $\mathrm{v}$ urbani pokrajini naraščal, prav tako pa tudi boj za njihovo prisvojitev s strani zelo različnih političnih skupin in njihovih ideoloških paradigem.

\section{CITIRANE REFERENCE}

BARThes, Roland 1993 Mythologies. London: Vintage.

Castleman, Craig 1999 Getting Up. Subway Graffiti in New York. Cambridge (MA): The MIT Press.

Chaffee, Lyman G. 1993 Political Protest and Street Art - Popular Tools for Democratization in Hispanic Countries, Westport: Greenwood Press.

Čolović, Ivan 2011 Za njima smo išli pjevajući - Junaci devedesetih. Beograd: Pelago. 2016 Smrt na Kosovom polju. Beograd: Biblioteka XX vek.

DeÁk, István 1990 Beyond Nationalism - A Social and Political History of the Habsburg Officer Corps 1848-1918. New York in Oxford: Oxford University Press.

1996 The One and the Many, v: Nader Mousavizadeh (ur.), The Black Book of Bosnia - The Consequences of Appeasement, The New Republic - BasicBooks, New York, str. 5-19.

Debord, GuY 1994 Society of Spectacle. New York: Zone Books.

41 Ta je v analizi kulta osebnosti kontroverznega koroškega politika Jörga Haiderja prišel do zaključkov, da je ta nastopal v treh samostojnih vlogah: kot Robin Hood (zaščitnik preprostib ljudi), kot športnik (eleganten in seksi, vedno v najboljši formi) in kot preprost človek (prijatelj, s katerim greš na pivo in čvekaš o vsem mogočem). 
Dedijer, Vladimir 1978 Sarajevo 1914. Beograd: Prosveta.

Dragićević ŠEšić, Milena 2014 Politike sećanja i disonantno nasleđe Balkana, str. 63-77. Niš: Balkanske sinteze.

Galántai, József 1989 Hungary in the First World War. Budapest: Akadémiai Kiadó.

Girardet, RaOul 1986 Mythes et mythologies politiques. Paris: Editions du Seuil.

JEZERNIK, BOŽIDAR 2013 Temeljni kamen kot kamen spotike - Vidovdan med Slovenci; Božidar Jezernik, Ingrid Slavec Gradišnik, Mitja Velikonja, ur. Politika praznovanja - Prazniki in oblikovanje skupnosti na Slovenskem, str. 17-46. Ljubljana: Znanstvena založba Filozofske fakultete Univerze v Ljubljani.

KropeJ, MoNika 2016 Rudolf Maister as a Symbol of Extreme Nationalism in Slovenia; referat na konferenci, znanstvena konferenca City, Symbols, Nationalism, Skopje, 18. in 19. maja.

LAMPE, JoHn R. 1996 Yugoslavia as History - Twice There Was a Country, Cambridge: Cambridge University Press.

Lipsitz, George 1997 Time Passages - Collective Memory and American Popular Culture. London: University of Minnesota Press, Minneapolis.

Lovata, Troy, Elizabeth Olton, ur. 2015 Understanding Graffiti - Multidisciplinary Studies From Prehistory to the Present. London: Routledge.

Lukec, Katarina 2016 Za jedne on je heroj, a drugima je zločinac - Gavrilo Princip u popularnoj kulturi 100 godina nakon sarajevskog atentata; Studia ethnologica Croatica, str. 315-337.

MacKenzie, David 1989 Apis: The Congenial Conspirator - The Life of Colonel Dragutin T. Dimitrijević. Boulder: East European Monographs.

Mojzes, Paul 1994 Yugoslavian Inferno - Ethnoreligious Warfare in the Balkans. New York: Continuum.

Mønnesland, Svein 2013 National Symbols in Multinational States: The Yugoslav Case. Oslo: Sypress Forlag.

Nova ković, Jelica, in Sven Peters 2015 Posledice jednog pucnja. Beograd: Clio.

Ottomeyer, Klaus 2000 Haiderjev Show. Ljubljana: Posebna izdaja Časopisa za kritiko znanosti.

Popović, Milica 2016 To Whom Does Gavrilo Princip Belong?; referat na konferenci, ASN Convention, Columbia University, New York.

RiefF, DAVID 1995 Slaughterhouse - Bosnia and the Failure of the West. New York: Simon \& Schuster.

SAUk Ko, PAUla 2003 Doing Research in Cultural Studies - An Introduction to Classical and New Methodological Approaches, London: Sage; New Delhi: Thousand Oaks.

Stojanović, Dubravka 2010 Ulje na vodi - Ogledi iz istorije sadašnjosti Srbije. Beograd: Čigoja štampa. 
Toš, NIKo, IDR. 2004 Vrednote v prehodu III. - Slovensko javno mnenje 1999-2004, Dokumenti SJM. Ljubljana: Fakulteta za družbene vede.

2016 Vrednote v prehodu X. - Slovensko javno mnenje 2010-2016, Dokumenti SJM. Ljubljana: Fakulteta za družbene vede.

West, RebecCA 1943 Black Lamb and Grey Falcon - A Journey Through Yugoslavia. New York: The Viking Press. 